\title{
Akgöl ve Gebekirse Göllerinde (Selçuk, İzmir, Türkiye) Bazı Fiziko-Kimyasal Parametrelerin Mevsimsel Değişimi
}

\author{
The Seasonal Changes of Some Physico-Chemical Parameters in Akgöl and Gebekirse \\ Lakes (Selçuk, İzmir, Turkey)
}

\author{
Orkide MINARECIं*1,a ${ }^{\text {Özge SUNGUR }}{ }^{2, b}$ \\ ${ }^{1}$ Manisa Celal Bayar Üniversitesi, Fen-Edebiyat Fakültesi, Biyoloji Bölümü, 45140, Yunusemre, Manisa \\ ${ }^{2}$ Manisa Celal Bayar Üniversitesi, Fen Bilimleri Enstitüsü, Biyoloji Anabilim Dall, 45140, Yunusemre, Manisa
}

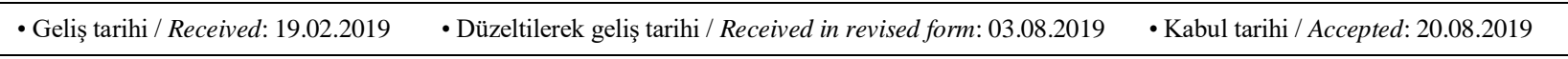

\begin{abstract}
$\ddot{O} \mathbf{z}$
Akgöl ve Gebekirse gölleri İzmir ili Selçuk ilçesi sınırları içindedir. Göller, Küçük Menderes Havzası'nda tarımsal sulamada kullanılmaktadır. Küçük Menderes Havzası önemli tarım bölgesi olduğundan, tarımsal sulamada kullanılan suyun kalite parametrelerinin bilinmesi ve izlenmesi sürdürülebilir bir tarım açısından önemlidir. Bu çalışmada, Akgöl ve Gebekirse göllerinin bazı fiziko-kimyasal özellikleri (sıcaklık, pH, toplam çözünmüş madde, iletkenlik, tuzluluk, orto fosfat fosforu, anyonik deterjan, bor, amonyum azotu, nitrit azotu, nitrat azotu) belirlenmiştir. Ortalama değerler Yerüstü Su Kalitesi Yönetmeliği'nde belirtilen kriter değerler ile karşılaştırıldığında, her iki göl sularının orto fosfat fosforu ve nitrit parametreleri açısından ikinci kalite su (az kirlenmiş su) olduğu belirlenmiştir. İletkenlik parametresi bakımından Akgöl’ün ikinci kalite (az kirlenmiş su), Gebekirse Gölü'nün üçüncü kalite (kirlenmiş su) su sınıfinda olduğu tespit edilmiştir. Ayrıca Gebekirse Gölü anyonik deterjan parametresi açısından da ikinci kalite (az kirlenmiş su) su sınıfindadır. Sulama suyu kriterlerine göre de, sıcaklık, $\mathrm{pH}$, bor, nitrat ve amonyum ortalama konsantrasyonlarının sınır değerlerin altında olduğu ve her iki göl sularının da bu parametreler açısından birinci sınıf sulama suyu olduğu görülmüş̧ür.
\end{abstract}

Anahtar kelimeler: Akgöl, anyonik deterjan, fosfor, Gebekirse Gölü, nitrit

\begin{abstract}
Akgöl and Gebekirse lakes are within the boundaries of Selçuk district of İzmir province. The lakes are used in agricultural irrigation in the Küçük Menderes Basin. Since the Küçük Menderes Basin is an important agricultural region, it is important to know and monitor the quality parameters of water used in agricultural irrigation. The some physico-chemical properties of Akgöl and Gebekirse lakes (temperature, pH, total dissolved substance, conductivity, salinity, ortho phosphate phosphorus, anionic detergent, boron, ammonium nitrogen, nitrite nitrogen, nitrate nitrogen) were determined in this study. When the mean values were compared with the criteria values specified in the Aboveground Water Quality Regulation, it was determined that both lake waters were second quality (less polluted water) in terms of ortho phosphate phosphorus and nitrite parameters. It was found that Akgöl was the second quality (less polluted water), Gebekirse Lake was the third quality (polluted water) in terms of conductivity parameter. In addition, Gebekirse Lake was the second quality (less polluted water) in terms of anionic detergent parameter. According to the irrigation water criteria, temperature, $\mathrm{pH}$, boron, nitrate and ammonium mean concentrations were below the limit values and both lake waters were first class irrigation water in terms of these parameters.
\end{abstract}

Keywords: Akgöl, anionic detergent, phosphorus, Gebekirse Lake, nitrite

\footnotetext{
*a Orkide MINARECI; orkide.minareci@cbu.edu.tr; Tel: (0236)2013278; orcid.org/0000-0001-6746-6057

borcid.org/0000-0002-9272-9717
} 


\section{Giriş}

Çevre ve su kirliliği hızlı nüfus artışı nedeniyle son dönemlerin en büyük sorunlarından biri haline gelmiştir. Dünya genelinde görülen bu sorun ülkemizde de artış göstermektedir (Küçükyılmaz vd., 2017). Çevre kirliliğinden birincil derecede etkilenen alıcı ortam özelliğinde olan göllerdir. Evsel, endüstriyel ve tarımsal aktiviteler neticesinde oluşan kirleticiler akarsular vasitasıyla göl ve denizlere ulaşmaktadır (Mutlu vd., 2013a). Tatlısuların fiziko-kimyasal özelliklerinin belirlenmesi, temiz suya olan gereksinimin fazlalaşmasıyla suyun düzenli olarak kullanılabilmesi için önem kazanmıştır. Su alanlarının kalitesinin bilinmesi amacıyla yapılan çalışmalar son zamanlarda giderek artmaktadır (Bulut vd., 2012).

Akgöl ve Gebekirse göllerinin içinde bulunduğu Küçük Menderes Deltası, çeşitli bataklık alanlar ile birlikte alanı 1500 hektardır. 1991'de SİT alanı olan delta, şimdi de Yaban Hayatı Koruma Sahası ve Önemli Kuş Alanıdır (Yarar ve Magnin, 1997). Akgöl ve Gebekirse gölleri, delta alanının kuzey yamaçlarına bitişiktir. Akgöl denize 5.5 km, Gebekirse Gölü $4.5 \mathrm{~km}$ uzaklıktadır (Erdenirsilay ve Tomar, 2011).

$\mathrm{Bu}$ göllerde daha önceden gerçekleştirilmiş çalışmalar su kalitesi ve çevresel etkilerin değerlendirilmesinden ziyade, göllerin biyolojik çeşitliliğinin belirlenmesine yönelik olmuştur. Ustaoğlu ve Balık (1987) tarafindan yapilan çalışmada Akgöl'de 23 Rotifer türü tespit edilmiştir. Ek olarak, Balık ve Ustaoğlu (1988), her iki gölün fizikokimyasal özellikleri ile birlikte balıkları ve balıkçılığı hakkında çalışmalar yapmış ve bu göllerde 12 balık türünü rapor etmişlerdir. Gebekirse Gölü zooplankton açısından da incelenmiş ve 20 tür tespit edilmiştir (Ustaoğlu ve Balik, 1990). Özbek (1997), Malacostraca (Crustacea-Arthropoda) faunası üzerine yaptığ1 çalışmasında Akgöl ve Gebekirse Gölü'nden 9 tür rapor etmiştir. Amphipoda (CrustaceaArthropoda) faunası ile ilgili çalışmada da, her iki gölden 4 Gammarus türü tespit edilmiştir (Özbek ve Ustaoğlu, 1998). Aysel vd. (2002), Barutçu Gölü (Akgöl) makro ve mikro alglerini incelemiş, 189 taksa bildirmişlerdir. Her iki gölün Cladocera ve Copepoda faunası incelenmiş, toplam 27 takson rapor edilmiştir (Ustaoğlu vd., 2006). Başka bir çalışmada Chironomidae familyasına ilişkin her iki gölden 5 tür rapor edilmiştir (Balık vd., 2006). Ustaoğlu vd. (2000), Malacostraca faunası ile ilgili çalışmada 4 ordoya ilişkin 11 tür tespit etmişlerdir. Her iki gölün Oligochaeta
(Annelida) faunasının belirlendiği çalışmada da 8 tür bulunmuştur (Yıldız vd., 2009).

Ülkemizin en verimli tarım alanlarına sahip Küçük Menderes Havzası, tarım, endüstri ve turizmin çok geliştiği, yerüstü ve yeraltı zenginlikleri olan, ülke ekonomisi bakımından çok önemli bir havzadır. Altyapı eksiklikleri, arıtma tesislerinin azlığ 1 , havzada planlamanın olmaması, göçlerle birlikte hızlı nüfus artışı gibi nedenlerle yüzeysel ve yeraltı suları kirlenmekte ve ekolojik denge bozulmaktadır (Gündoğdu ve Özkan, 2006). Akgöl, son y1llarda yukarıda belirtilen nedenlerden dolay1 kirliliğgin arttığı Küçük Menderes Nehri ile birleşmektedir. Ayrıca Akgöl ve Gebekirse Gölü etrafinda tarım alanları da çoktur. Tarımsal gübrelerin ve ilaçların göllere etkisinin belirlenmesi ve yakın yerleşim yerlerinin evsel atıklarının göllere ulaşabileceği düşünülerek bu çalışmada, Akgöl ve Gebekirse göllerinin bazı fizikokimyasal parametrelerinin tespit edilmesi ve su kalitesi değişkenlerinin mevsimsel olarak belirlenmesi amaçlanmıştır.

\section{Gereç ve Yöntem}

Akgöl 37059'31.85"''K - 27019"5.90"''D ve Gebekirse Gölü 37059'11.32"'’K $27^{\circ} 18^{\prime \prime} 15.66^{\prime \prime}$ 'D koordinatları arasinda yer almaktadır ve göller İzmir ili Selçuk ilçesi sınırları içerisindedir (Şekil 1).

Akgöl, alüvyon baraj göllerindendir ve yapay bir kanalla Küçük Menderes nehri ve dolayısıyla Ege Denizi'ne bağlanır. Yüzey alanı yaklaşık 75 hektar, derinliği 4 m, pH'1 7.5-8 arasındadır. Çevresindeki tatlı su kaynakları ve yağmur sularıyla beslenir (Aysel vd., 2002). Akgöl'e, Barutçu Gölü veya Çatal Gölü de denmektedir (Ustaoğlu vd., 2006).

Gebekirse Gölü de oluşum bakımından alüvyon baraj gölleri grubundadır. Beslenmesi karstik mermerlerden ve yağışlardan kaynaklanmakta iken, bir kanal yardımıyla Küçük Menderes Nehri'ne ve dolayisiyla Ege Denizi'ne dökülmektedir. Gebekirse Gölü' nün yüzey alanı 75 hektar, maksimum derinliği ise $5 \mathrm{~m}$ civarındadır (Ustaoğlu vd., 2000).

Kasım 2015 - Haziran 2016 tarihleri arasında, Kasım, Ocak, Nisan ve Haziran aylarında, belirlenen istasyonlardan alınan su örneklerinin bazı fiziko-kimyasal parametreleri mevsimsel olarak saptanmıştır. İletkenlik, pH, sıcaklık, tuzluluk, toplam çözünmüş madde parametreleri araştırma alanında TOA WQC (Water Quality Checker) - 20A ile ölçülmüştür. 


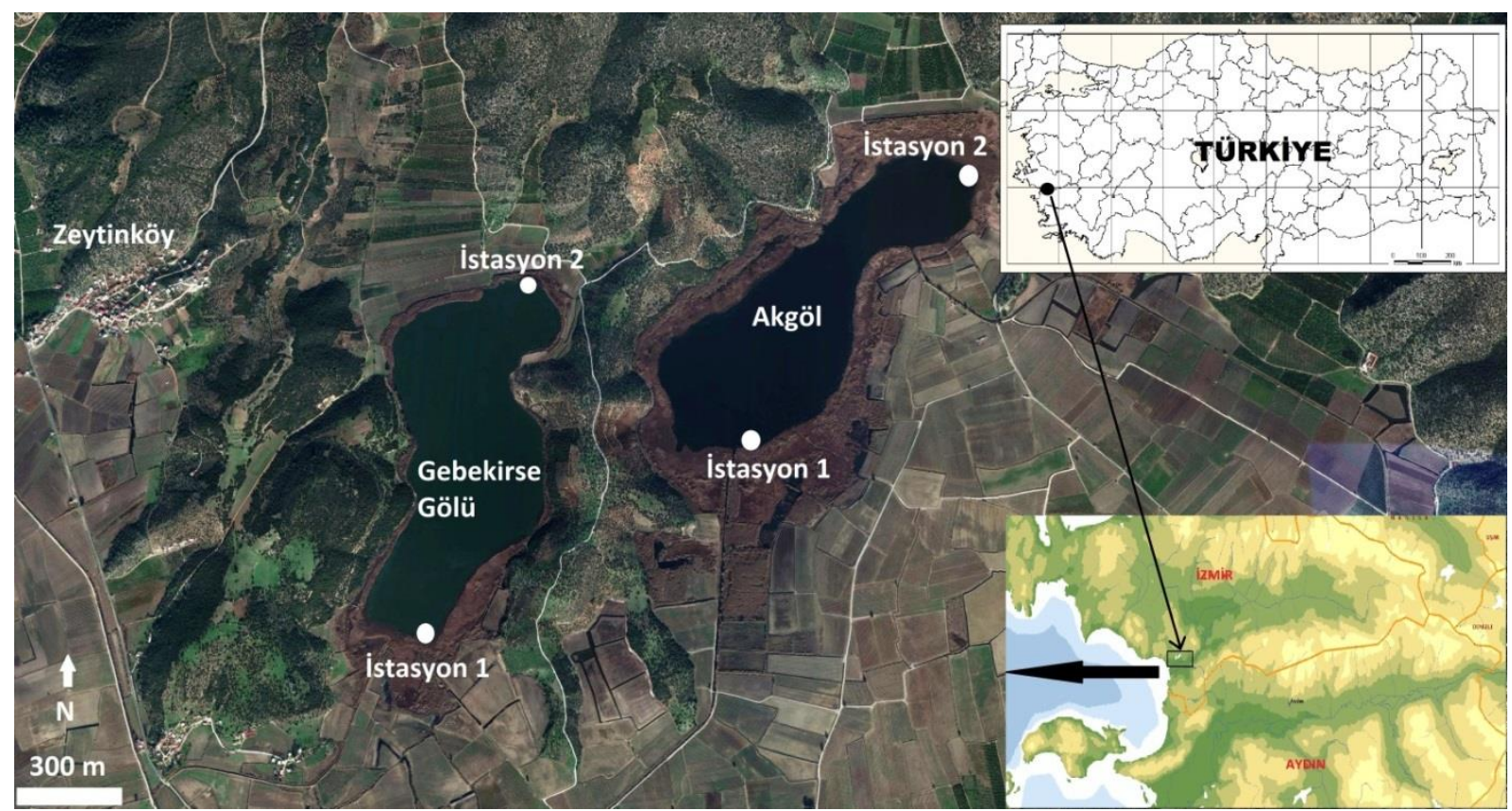

Şekil 1. Akgöl ve Gebekirse Gölü

Renk ve koku parametreleri gözlemsel yol ile belirlenmiştir. Nitrit, nitrat, fosfat, amonyum, anyonik deterjan, bor miktarlarının belirlenmesi için su örnekleri $500 \mathrm{~mL}$ 'lik polietilen şişelere alınmıştır.

Anyonik yüzey aktif maddeler ile metilen mavisi reaksiyona girdikten sonra oluşan tuz kloroformda çözülmüş ve spektrofotometrede ölçülerek anyonik deterjan tayin edilmiştir (Anonim, 1995). Orto-fosfat fosforu, asidik ortamda amonyum molibdat, potasyum antimonil tartarat ve askorbik asit ile reaksiyona girmiş ve oluşan mavi renkli fosfomolibdik asidin spektrofotometrede ölçülmesiyle saptanmıştır (Parsons vd., 1984). Borun spesifik bir reaktif olan karmin ile oluşturduğu kırmızı renkli bileşiğin spektrofotometrede ölçülmesiyle bor miktarı belirlenmiştir (Hatcher and Wilcox, 1950; Anonim, 2005). Nitrit, nitrat ve amonyum miktarları da fotometrik yöntemler kullanılarak (Strickland ve Parsons, 1972), araştırma laboratuvarımızda ölçülmüştür.

\section{Bulgular ve Tartışma}

Akgöl'de ortalama sicaklık $18.68{ }^{\circ} \mathrm{C}, \mathrm{pH}$ 7.50, toplam çözünmüş madde $125 \mathrm{mg} \mathrm{L}^{-1}$, iletkenlik $925 \mu \mathrm{S} / \mathrm{cm}$, tuzluluk \%o 0.52 , orto fosfat fosforu $0.0779 \mathrm{mg}$ o- $\mathrm{PO}_{4}-\mathrm{P} \mathrm{L}^{-1}$, anyonik deterjan 0.0469 $\mathrm{mg} \mathrm{L}^{-1}$, bor $0.4823 \mathrm{mg} \mathrm{L}^{-1}$, amonyum azotu $0.1658 \mathrm{mg} \mathrm{L}^{-1}$, nitrit azotu $0.0032 \mathrm{mg} \mathrm{L}^{-1}$ ve nitrat azotu $0.0403 \mathrm{mg} \mathrm{L}^{-1}$ bulunmuştur (Tablo 1). Gebekirse Gölü'nde ortalama sıcaklık $19.65{ }^{\circ} \mathrm{C}$,
pH 7.28, toplam çözünmüş madde $125.5 \mathrm{mg} \mathrm{L}^{-1}$, iletkenlik $1025 \mu \mathrm{S} / \mathrm{cm}$, tuzluluk \%o 0.55 , orto fosfat fosforu $0.0751 \mathrm{mg}$ o- $\mathrm{PO}_{4}-\mathrm{P} \mathrm{L}^{-1}$, anyonik deterjan $0.1026 \mathrm{mg} \mathrm{L}^{-1}$, bor $0.517 \mathrm{mg} \mathrm{L}^{-1}$, amonyum azotu $0.1009 \mathrm{mg} \mathrm{L}^{-1}$, nitrit azotu 0.0031 $\mathrm{mg} \mathrm{L}^{-1}$ ve nitrat azotu $0.0537 \mathrm{mg} \mathrm{L}^{-1}$ bulunmuştur (Tablo 2). Ayrıca gözlemsel olarak, göllerin berrak ve kokusuz olduğu görülmüştür.

Akgöl ve Gebekirse Gölü'nün belirlenen istasyonlarından alınan su örneklerinin fizikokimyasal parametrelerin analizi yapılarak mevsimsel değişimleri gösterilmiştir. Fizikokimyasal parametreler, "Yerüstü $\mathrm{Su}$ Kalitesi Yönetmeliği" çerçevesinde "Kıtaiçi Yüzeysel Su Kaynaklarının Sınıflarına Göre Kalite Kriterleri" (Resmi Gazete, 2012) ile karşılaştırıldığında iletkenlik parametresi bakımından Akgöl'ün II. sınıf, Gebekirse Gölü'nün III. sınıf su kalitesine sahip olduğu tespit edilmiştir. Her iki göl sularının orto fosfat fosforu ve nitrit parametreleri yönünden II. kalite su sinıfında olduğu saptanmıştır (Tablo 3).

Elde ettiğimiz anyonik deterjan değerleri de "Su Kirliliği Kontrolü Yönetmeliğì"nde (Resmi Gazete, 2004) belirtilen metilen mavisiyle reaksiyon veren yüzey aktif maddeler ile karşılaştırılmıştır. Gebekirse Gölü'ndeki ortalama anyonik deterjan değerinin $\left(0.1026 \mathrm{mg} \mathrm{L}^{-1}\right)$, alt limit değerden $\left(0.05 \mathrm{mg} \mathrm{L}^{-1}\right)$ yüksek olduğu ve anyonik deterjan parametresi yönünden Gebekirse Gölü'nün II. kalite su sinıfinda olduğu görülmüştür. 


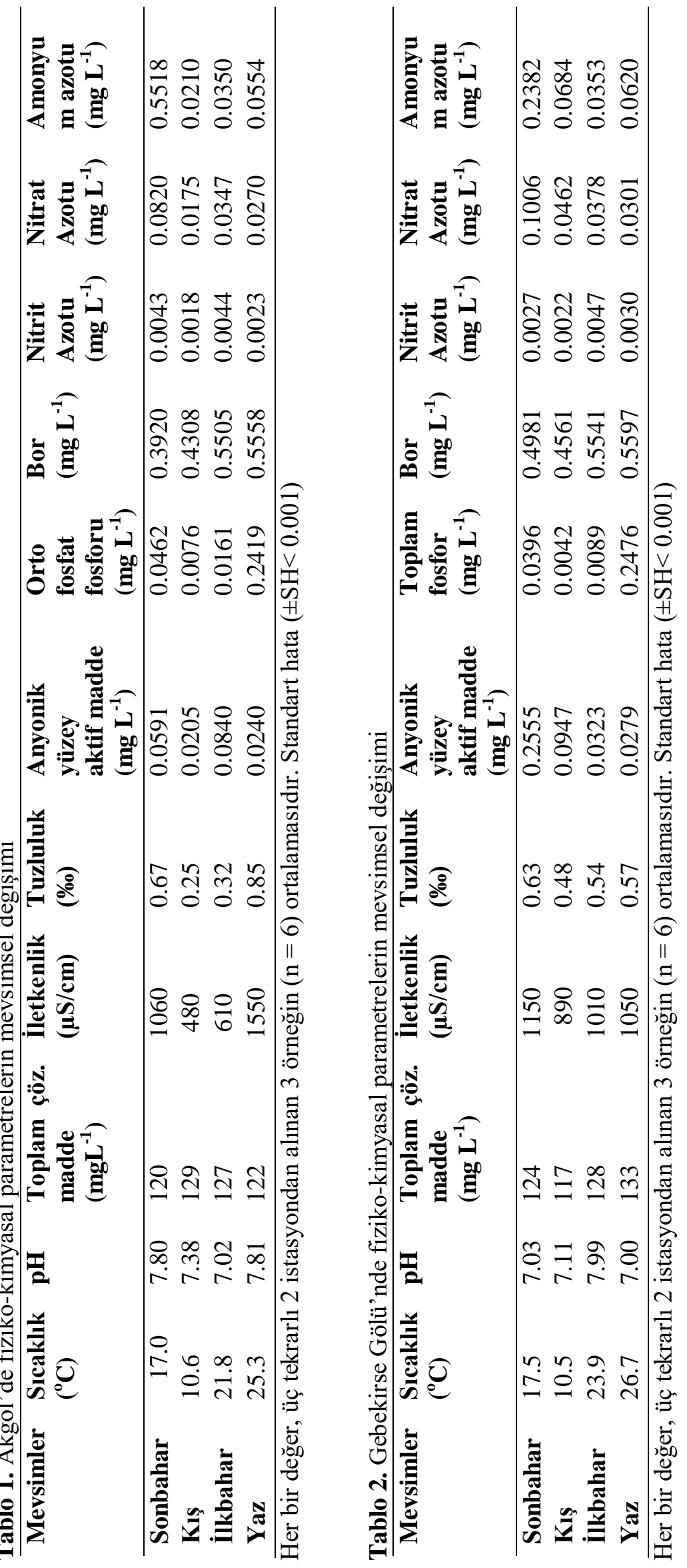


Tablo 3. Kıtaiçi Yüzeysel Su Kaynaklarının Sınıflarına Göre Kalite Kriterleri ile Karşılaştırma

\begin{tabular}{|c|c|c|c|c|c|c|}
\hline \multirow{2}{*}{$\begin{array}{l}\text { Su Kalite } \\
\text { Parametreleri }\end{array}$} & \multicolumn{4}{|c|}{ Su Kalite Sınıfları } & \multicolumn{2}{|c|}{ Bu Çalışma } \\
\hline & I & II & III & IV & Akgöl & Gebekirse \\
\hline Sicaklık $\left({ }^{0} \mathrm{C}\right)$ & $\leq 25$ & $\leq 25$ & $\leq 30$ & $>30$ & 18.68 & 19.65 \\
\hline $\mathrm{pH}$ & $6-9$ & $6-9$ & $6-9$ & $6-9$ & 7.50 & 7.28 \\
\hline 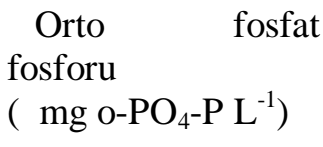 & $<0.05$ & 0.16 & 0.65 & $>0.65$ & 0.0779 & 0.0751 \\
\hline $\begin{array}{l}\text { Amonyum azotu } \\
\left(\mathrm{mg} \mathrm{L}^{-1}\right)\end{array}$ & $<0.2$ & 1 & 2 & $>2$ & 0.1658 & 0.1009 \\
\hline Nitrit $\left(\mathrm{mg} \mathrm{L}^{-1}\right)$ & $<0.002$ & 0.01 & 0.05 & $>0.05$ & 0.0032 & 0.0031 \\
\hline Nitrat $\left(\mathrm{mg} \mathrm{L}^{-1}\right)$ & $<3$ & 10 & 20 & $>20$ & 0.0403 & 0.0537 \\
\hline $\begin{array}{l}\text { İletkenlik } \\
(\mu \mathrm{S} / \mathrm{cm})\end{array}$ & $<400$ & 1000 & 3000 & $>3000$ & 925 & 1025 \\
\hline
\end{tabular}

Her iki gölün etrafinda tarım yapıldığından, göl sularında fosfor ve nitrit miktarlarındaki artışın tarımda kullanılan gübrelerden, Gebekirse Gölü'ndeki anyonik deterjan yükünün göl yakınındaki yerleşim yeri olan Zeytinköy'ün evsel atıklarından kaynaklandığı düşünülmektedir. Ayrıca Gebekirse Gölü’nde iyon yükünden dolayı iletkenlik değerleri de yüksektir.

Ayrıca bu göller, sulama amaciyla da kullanıldığı için, "Su Kirliliği Kontrolü Yönetmeliği Teknik Usuller Tebliği"nde (Resmi Gazete, 1991) belirtilen "Sulama Sularının Sinıflandırılmasında Esas Alınan Sulama Suyu Kalite Parametreleri" ile karşılaştırma yapıldığında, sıcaklık, $\mathrm{pH}$, bor, nitrat ve amonyum ortalama konsantrasyonlarının sınır değerlerin altında olduğu ve her iki göl sularının da bu parametreler açısından birinci sınıf sulama suyu olduğu görülmüştür.

Çalışma sonucu elde ettiğimiz değerler, daha önce bu göllerde yapılmış çalışmalarda elde edilen değerler ile karşılaştırılmıştır. Balık ve Ustaoğlu (1988)'nun yaptığı çalışmada bulunan değerler ile bizim çalışmamızda bulduğumuz değerleri karşılaştırdığımızda, Akgöl'de sicaklık, pH, turbidite, nitrit ve nitrat değerlerinin benzer olduğu, fosfat ve amonyum değerlerinin arttı̆̆1, tuzluluk değerinin düştüğü, Gebekirse Gölü’ndeki değerlerde ise çok farklılık olmadığı görülmüştür. Yine aynı göllerde yapılan başka çalışmalarda elde edilmiş olan değerlerle karşılaştırma yaptığımızda, iletkenlik, tuzluluk (Yildız vd., 2010) değerlerinin yanında fosfat ve nitrat
(Kaymakçı Başaran, 2011) değerlerinin bizim çalışmamızda daha düşük olduğu görülmüştür.

Çeşitli nedenlerle su kirliliğinin artmasından dolayı, çok sayıda su kalitesinin belirlendiği çalışma yapılmış ve son yıllarda göllerde kirlilik olaylarının hızla arttığ 1 görülmüştür. Çalışmamızda elde ettiğimiz sonuçlara benzer olarak göllerde yapılan su kalitesi çalışmalarında da göl suları kalite sınıflarına ayrılmış, kirlilik düzeyleri belirlenmiştir.

Bizim çalışma yaptığımız göller ile aynı bölgede olan ve etrafında tarım yapılan Çivril Gölü'nde (Denizli) fizikokimyasal parametreler ölçülmüş ve organik kirliliğin özellikle yaz mevsiminde çok $\operatorname{arttığ1~ve~organik~kirliliğe,~tarımsal~faaliyetler~}$ sonucu oluşan tarımsal kirlilik ve Büyük Menderes Nehri ile çevre derelerden gelen yağģ̧ sularının sebep olduğu ve bizim çalışma yaptığımız göllere benzer olarak, gölün evsel kullanımlar ve tarımsal uygulamalardan dolayı olumsuz yönde etkilendiği belirtilmiştir (Bulut vd., 2012).

Yine aynı bölgede bulunan Manisa ilindeki Sevişler, Demirköprü, Avşar ve Gölmarmara göllerinde yapılan çalışma sonucunda, anyonik yüzey aktif madde ve fosfat yönünden, bütün istasyonlardan alınan su I. sınıf yani yüksek kaliteli su sınıfında bulunmuştur. Çalışmamızda elde ettiğimiz değerlerin aksine, evsel, endüstriyel ve tarımsal faaliyetlerden kaynaklanan deterjan ve fosfat miktarlarının limit değerlerin altında olduğu 
görülmüştür (Minareci vd., 2010). Yine bu göllerde bor konsantrasyonlarını belirlemek amacıyla yapılan diğer bir çalışmada da, Akgöl ve Gebekirse göllerinin aksine, Avşar Gölü IV. sınıf (çok kirlenmiş su) kalitesinde bulunmuştur (Minareci ve Öztürk, 2012).

Bölgemiz dışındaki göllerden Uluabat Gölü'nde (Bursa), mevsimsel olarak su kalitesi değerlendirilmiş ve çalışmada, göl suyu, Su Kirliliği Kontrol Yönetmeliği ve sulama suyu kriterlerine göre IV. sınıf kalitede, İnsani Tüketim Amaçlı Sular (Türk Standardı 266, 2005) kriterlerine göre içme ve kullanma suyu limit değerlerinin üzerinde bulunmuştur (Katip ve Karaer, 2011). Sulama suyu kriterlerine göre nitrat ve amonyum değerleri bizim çalışmamızdaki gibi düşük, iletkenlik değerleri de bizim çalışmamızdaki değerlere benzerdir. Su Kirliliği Kontrol Yönetmeliği kriterlerine göre de, amonyuma göre II. sinıf, nitrata göre bizim çalışmamızdaki gibi I. sınıf bulunmuş ve fosfor değerleri de bizim çalışmamızdaki gibi kriter değerlerin üzerinde tespit edilmiştir. Uluabat Gölü su kalitesinin bozulduğu, özellikle içme ve kullanma amaçlı olarak kullanılamayacağ sulama amaçlı olarak ihtiyatlı kullanılması gerektiğii, endüstriyel kullanım açısından da uygun olmadığ 1 ancak arıtma yapıldıktan sonra kullanılabileceği belirlenmiştir.

Yine Uluabat Gölü'nde yapılan başka bir çalışmada, gölün su kalitesi, Su Kirliliği Kontrol Yönetmeliği'ne göre IV. sınıf, Tarım ve Köy İşleri Bakanlığı Su Ürünleri Yönetmeliği’ne göre amonyum, magnezyum, bakır, kadmiyum ve çinko değerleri limit değerlerin üzerinde saptanmıştır (Elmac1 vd., 2010). Uluabat Gölü’nün elektriksel iletkenlik değeri $555.75 \mu \mathrm{S}$ $\mathrm{cm}^{-1}$ bulunmuş ve bizim çalışmamızdaki değerlere benzer olarak kriter değerin üzerindedir. $0.52 \mathrm{mg}$ $\mathrm{l}^{-1}$ olan amonyum azotu değeri Akgöl ve Gebekirse göllerinde elde edilen değerlerden yüksektir. Uluabat Gölü'nde ölçülen ortofosfat fosforu konsantrasyonu $0.07 \mathrm{mg} \mathrm{l}^{-1}$, dir ve SKKY'deki sınır değerini $\left(0.05 \mathrm{mg} \mathrm{l}^{-1}\right)$ bizim çalışmamızdaki gibi aştı̆g 1 görülmektedir. Ayrıca toplam azot ve toplam fosfor açısından kirlenmiş su kalitesine sahip olduğu görülmektedir. Bunun başlıca sebebinin de, çalışmamızda da belirttiğimiz gibi, göl çevresindeki yerleşim yerlerinden göle bırakılan evsel atık sular, tarımsal atıklar ve foseptiklerden gelen sizıntı suları olabileceği bildirilmiştir.

Yine bu gölde yapılan diğer bir araştırma sonucunda da, fiziko-kimyasal parametrelerin konsantrasyonları yaz mevsiminde yüksek bulunmuştur (İleri vd., 2014).

Sivas'ta bulunan Karagöl'de de bizim çalışmamızdaki gibi, mevsimsel olarak su kalitesi değerlendirme çalışması yapılmıştır (Mutlu vd., 2013a). SKKY göre pH açısından su kalitesi I III sınıf arasında değişmiş, elektriksel iletkenlik değeri yönünden de SKKY'ye göre göl I. sınıf su kalitesinde bulunmuş ve bizim çalıştığımız göllerdeki gibi değerlerin kış ve ilkbahar aylarında düşük, yaz ve sonbahar aylarında daha yüksek olduğu görülmüştür. Gölün ortalama fosfor değeri $0.21 \mathrm{mg} / \mathrm{L}$ olup, su SKKY göre III. sinif su olarak tespit edilmiştir. Akgöl ve Gebekirse Gölleri de fosfat parametresi açısından II. sınıf bulunmuştur.

Yine Sivas ilinde bulunan Kurugöl, Su Kirliliği Kontrol Yönetmeliği (SKKY)'ne göre değerlendirildiğinde I. ve III. sınıf su kalitesinde olduğu saptanmıştır (Mutlu vd., 2013b). Kurugöl'de amonyum azotu, nitrit ve nitrat oldukça düşük değerlerde bulunmuştur ve SKKY göre I. sınıf su özelliğindedir. Akgöl ve Gebekirse Gölü'nde ise benzer olarak amonyum azotu ve nitrat değerleri düşük olmasına karşın, nitrit değerleri yüksektir. Ayrıca bizim çalışma yaptığımız göllerde elektriksel iletkenlik değerleri yüksek olmasına karşın, Kurugöl elektriksel iletkenlik değeri bakımından SKKY göre I. kalite su sinıfindadır.

Eğirdir Gölü’nde (Isparta) fiziko-kimyasal parametre verileri belirlenmiş ve göl limnolojik açıdan değerlendirilmiştir. Çalışmada fizikokimyasal parametrelerin önemli risk taşımadığı fakat organik madde kirliliğinden dolayı bazı parametrelerin yüksek değerde olduğu saptanmıştır. Bazı istasyonlarda özellikle yazın organik madde miktarındaki artış ve çözünmüş oksijen miktarındaki azalma bunu doğrulamaktadır (Bulut vd., 2009). Bizim çalışmamızda yüksek olan değerler ile karşılaştırdığımızda, elektriksel iletkenlik, nitrat ve fosfat değerlerinin daha düşük olduğu görülmüştür.

Hazar Gölü'nde yapılan çalışmada değerler $\mathrm{Su}$ Kirliliği Kontrolü Yönetmeliği ile değerlendirilmiş, ötrofikasyon kontrol sınır değerleriyle karşılaştırılmış ve Hazar Gölü I. ve III. su sinıfinda bulunmuştur. Fakat fosfor açısından IV. sınıf olduğu belirtilmiştir (Ünlü vd., 2008). Bizim çalışmamızda elde ettiğimiz değerlere göre göl suları fosfor açısından az kirlenmiş su sınıfinda bulunmuştur. Hazar Gölü’nde ölçülen elektriksel iletkenlik ortalama 
değeri sulama suyu açısından değerlendirildiğinde IV. sınıf su kalite grubuna girdiği ve dolayısıyla sulamaya elverişsiz olduğu görülmektedir. Akgöl ve Gebekirse göllerindeki elektriksel iletkenlik ortalama değerleri de yüksek olup, Akgöl'ün II. sınıf, Gebekirse Gölü'nün III. sınıf su kalitesine sahip olduğu tespit edilmiştir.

\section{Sonuç ve Öneriler}

İzmir ili Selçuk ilçesi sınırları içinde bulunan Akgöl ve Gebekirse gölleri etrafında tarım yapılmaktadır ve göl suları tarımsal sulamada kullanılmaktadır. Küçük Menderes Havzası önemli tarım bölgesi olduğundan, tarımsal sulamada kullanılan suyun kalite parametrelerinin bilinmesi ve izlenmesi sürdürülebilir bir tarım açısından önemlidir. Sonuç olarak, göl sularında fosfor ve nitrit miktarlarındaki artış, tarımda kullanılan fosfatlı ve azotlu gübrelerden olabileceğinden, tarımda kullanılan kimyasal gübrelerin ve tarım ilaçlarının kullanımı konusunda çiftçilerin bilinçlendirilmesi gerekmektedir. Toprak yapısı analizlerinin yapılmas1, toprak yapısina en uygun ve yeterli miktarda gübrenin kullanılması uygun olacaktır. Ayrıca teraslama yapılarak tarımsal gübre ve ilaçların yağışlarla göle ulaşması engellenebilir.

Gebekirse Gölü’ndeki anyonik deterjan yükünün göl yakınındaki yerleşim yeri olan Zeytinköy'ün evsel atıklarından kaynaklandığı düşünülmektedir. Deterjan kirliliğinin önlenmesi için öncelikli olarak biyolojik parçalanabilirliği yüksek olan yüzey aktif maddeler tercih edilmeli ve göle ulaşması engellenmelidir.

Ayrica sicaklık, pH, bor, nitrat ve amonyum ortalama değerlerinin, sulama suyu kriter değerlerinden düşük olması, bu parametreler bakımından göl sularının sulama suyu olarak kullanılması için uygundur.

\section{Kaynaklar}

Anonim, 1995. Standard methods for the examination of water and wastewater: 19th Edition, APHA, AWWA, WPCF, Washington.

Anonim, 2005. Standard methods for the examination of water and wastewater: 21st Edition, APHA, AWWA, WEF, Washington.

Aysel, V., Gezerler-Şipal, U., Aysel, F., Erduğan, H. ve Türker, E., 2002. Barutçu Gölü'nün (Selçuk, İzmir, Türkiye) Mikro ve Makro Algleri. Ege Üniversitesi Su Ürünleri Dergisi, 19(1-2), 1-11.
Balık, S. ve Ustaoğlu, M.R., 1988. Akgöl ve Gebekirse Gölünün (Selçuk-İzmir) Fiziko-kimyasal Özellikleri, Balıkları ve Balıkçılığı. IX. Ulusal Biyoloji Kongresi, Zooloji ve Hidrobiyoloji Seksiyonu, 21-23 Eylül 1988, Sivas, Cilt 2, s. 367-376.

Balık, S., Ustaoğlu, M.R., Özbek, M., Yıldız, S., Taşdemir, A. ve İlhan, A., 2006. Küçük Menderes Nehri'nin (Selçuk- İzmir) Aşağ1 Havzasındaki Kirliliğin Makro Bentik Omurgasızlar Kullanılarak Saptanması. Ege Üniversitesi Su Ürünleri Dergisi, 23(1-2), 6165.

Bulut, C., Atay, R. ve Uysal, K., 2009. Eğirdir Gölü'nde Fiziko-kimyasal Parametrelerin Mevsimsel Değişimi ve Limnolojik Açıdan Değerlendirilmesi. Anadolu Üniversitesi Bilim ve Teknoloji Dergisi, 10(2), 447-454.

Bulut, C., Atay, R., Uysal, K. ve Köse, E., 2012. Çivril Gölü Yüzey Suyu Kalitesinin Belirlenmesi. Anadolu Üniversitesi Bilim ve Teknoloji Dergisi-C Yaşam Bilimleri ve Biyoteknoloji, 2(1), 1-8.

Elmacı, A., Topaç, F.O., Teksoy, A., Özengin, N. ve Başkaya, H.S., 2010. Uluabat Gölü Fizikokimyasal Özelliklerinin Yönetmelikler Çerçevesinde Değerlendirilmesi. Uludağ Üniversitesi Mühendislik-Mimarlık Fakültesi Dergisi, 15(1), 149-157.

Erdenirsilay, A. ve Tomar, A., 2011. Küçük Menderes Havzasında Su Kaynaklarının Geliştirilmesinin Kıyı Bölgesine Olan Etkileri. 7. Kıyı Mühendisliği Sempozyumu, 21-23 Kasım 2011, Trabzon, s. 37-44.

Gündoğdu, V. ve Özkan, E.Y., 2006. Küçük Menderes Nehri Ölçüm Ağı Tasarımı ve Su Kalite Değişkenlerinin İrdelenmesi Çalışması. Ege Üniversitesi Su Ürünleri Dergisi, 23(3- 4), 361369.

Hatcher, J.T. ve Wilcox, L.V., 1950. Colorimetric determination of boron using. Analytical Chemistry, 22(4), 567-569.

İleri, S., Karaer, F., Kâtip, A. ve Onur, S., 2014. Sı ̆ Göllerde Su Kalitesi Değerlendirmesi, Uluabat Gölü Örneği. Uludağ Üniversitesi MühendislikMimarlık Fakültesi Dergisi, 19(1), 47-57.

Kâtip, A. ve Karaer, F., 2011. Uluabat Gölü su kalitesinin Türk Mevzuatına ve Uluslararas1 Kriterlere Göre Değerlendirilmesi. Uludağ Üniversitesi Mühendislik-Mimarlık Fakültesi Dergisi, 16 (2), 25-34.

Kaymakçı Başaran, A., 2011. Investigation of Water Quality and Heavy Metal Levels in Sediment in Küçük Menderes River Deltaic Zone (Selçuk, 
İzmir, Turkey). Journal of Animal and Veterinary Advances, 10(24), 3274 - 3280.

Küçükyılmaz, M., Uslu, G., Birici, N., Örnekçi, N.G., Yıldız, N. ve Şeker, T., 2017. Karakaya Baraj Gölü Su Kalitesinin İncelenmesi. Yunus Araştırma Bülteni, 2, 145-155.

Minareci, O., Öztürk, M., Kalyoncu, F. ve Minareci, E., 2010. Manisa İli Baraj Göllerinde Deterjan Kirliliği ve Mikrobiyolojik Kirliliğin Araştırılması. Celal Bayar Üniversitesi Bilimsel Araştırma Projesi Kesin Raporu, Manisa, 38 s.

Minareci, O. ve Öztürk, M., 2012. Manisa İli Baraj Göllerinde Bor Kirliliğinin Araştırılması. Biyoloji Bilimleri Araştırma Dergisi, 5(1), 2529.

Mutlu, E., Yanık, T. ve Demir, T., 2013a. Karagöl (Hafik-Sivas) 'ün $\mathrm{Su}$ Kalitesinin İncelenmesi. Alınteri Zirai Bilimler Dergisi, 24(B), 35-45.

Mutlu, E., Demir, T., Kutlu, B. ve Yanık, T., 2013b. Sivas-Kurugöl $\mathrm{Su}$ Kalite Parametrelerinin Belirlenmesi. Türk Tarım - Gıda Bilim ve Teknoloji Dergisi, 1(1), 37-43.

Özbek, M., 1997. İzmir İli ve Civarı Tatlısu Malacostraca (Crustacea-Arthropoda) Faunas1. Yüksek Lisans Tezi, Ege Üniversitesi Fen Bilimleri Enstitüsü, İzmir, 92 s.

Özbek, M. ve Ustaoğlu, M.R., 1998. İzmir İli ve Civarı İçsularının Amphipoda (Crustacea-Arthropoda) Faunasi. Ege Üniversitesi Su Ürünleri Dergisi, 15(3-4), 211-231.

Parsons, T.R., Maitia, Y. ve Lalli, C.M., 1984. A manual of chemical and biological methods for sea water analysis: New York, Pergamon Press, $173 \mathrm{p}$.

Resmi Gazete, 1991. Su Kirliliği Kontrolü Yönetmeliği Teknik Usuller Tebliği, Tarih 07.01.1991, Sayı 20748.

Resmi Gazete, 2004. Su Kirliliği Kontrolü Yönetmeliği, Tarih 31.12.2004, Sayı 25687.

Resmi Gazete, 2012. Yerüstü Su Kalitesi Yönetmeliği, Tarih 30.11.2012, Say1 28483.
Strickland, J.D.H. ve Parsons, T.R., 1972. A Practical Handbook of Seawater Analysis: Second Edition: Canada, Fisheries Research Board of Ottowa, Bulletin No: 167, 310 p.

Türk Standardı 266 (TS 266)., 2005. Sular-İnsani Tüketim Amaçlı Sular. Türk Standardları Enstitüsü, Ankara.

Ustaoğlu, M.R. ve Balık, S., 1987. Akgöl'ün Rotifer Faunasi. VIII. Ulusal Biyoloji Kongresi, Zooloji, Hidrobiyoloji, Temel ve Endüstriyel Mikrobiyoloji Tebliğleri, 3-5 Eylül 1986, İzmir, Cilt 2, s. 614-626.

Ustaoğlu, M.R. ve Balık, S., 1990. Zooplankton of Lake Gebekirse (İzmir-Turkey). Rapp. Comm. Int. Mer Medit., 32(1), 74.

Ustaoğlu, M.R., Balık, S. ve Özbek, M., 2000. Akgöl ve Gebekirse Gölü'nün (Selçuk-İzmir) Malacostraca Faunası. XV. Ulusal Biyoloji Kongresi, 5 - 9 Eylül 2000, Ankara Üniversitesi, Fen Fakültesi, Biyoloji Bölümü, Ankara, s. 217222.

Ustaoğlu, M.R., Balık, S., Aygen, C. ve Özdemir Mis, D., 2006. Akgöl'ün (Selçuk, İzmir) Kladoser ve Kopepodları. Ege Üniversitesi $\mathrm{Su}$ Ürünleri Dergisi, 23(1/1), 169-172.

Ünlü, A., Çoban, F. ve Tunç, M.S., 2008. Hazar Gölü $\mathrm{Su}$ Kalitesinin Fiziksel ve İnorganik Kimyasal Parametreler Açısından İncelenmesi. Gazi Üniversitesi Mühendislik Mimarlık Fakültesi Dergisi, 23(1), 119-127.

Yarar, M. ve Magnin, G., 1997. Türkiye'nin Önemli Kuş Alanları. İstanbul: Doğal Hayatı Koruma Derneği Yayınları, $313 \mathrm{~s}$.

Yıldız, S., Ustaoğlu, M.R. ve Balık, S., 2009. Akgöl ve Gebekirse Gölü'nün (Selçuk-İzmir) Oligochaeta Faunası (Annelida). Review of Hydrobiology, 2, 173-186.

Yıldız, S., Özbek, M., Taşdemir, A. ve Balık, S., 2010. Identification of Predominant Environmental Factors Structuring Benthic Macro Invertebrate Communities: A Case Study in the Küçük Menderes Coastal Wetland (Turkey). Fresenius Environmental Bulletin, 19(1), 30-36. 